Lewin, R. A. (1958). J. gen. Microbiol. 19, 87-90

\title{
The Cell Walls of Platymonas
}

\author{
By R. A. LEWIN \\ Marine Biological Laboratory, Woods Hole, Mass., U.S.A.
}

SUMMARY: Electron micrographs of cell walls of the unicellular green flagellate Platymonas subcordiformis revealed no evidence of a fibrous construction. A preparation of walls was isolated, hydrolysed, and analysed by paper chromatography. The major components indicated were galactose and a uronic acid; glucose was not detected. It was concluded that the cell walls of this alga are not composed of cellulose.

A strong case can be made for the close phylogenetic relationship between higher plants and green algae. Among the accepted features of resemblance are the nature of the plastid pigments, the storage of starch, and the presence of a cellulose wall. However, there are few cases in which the chemical nature of the walls of green algae has been critically examined. Most of the evidence is indirect, being based on their birefringence, solubility in cuprammonium solutions, or staining reactions (Fritsch, 1935). The walls of many of the larger filamentous forms have been shown under the electron microscope to be composed of fibrils which in size agree with those of cellulose from Angiosperms; $\mathrm{X}$-ray diffraction studies indicate that they are, in fact, some form of cellulose (Nicolai \& Preston, 1952). In Spirogyra, half of the cell-wall material can be dissolved by successive extractions with hot dilute alkali and acid, and yields galactose and xylose on hydrolysis; but the remainder appears to consist of cellulose (Kreger, 1957). In some species of unicellular green algae, however, cellulose may not be present at all. The walls of several members of the Chlorococcales, including Ankistrodesmus falcatus (Sponsler \& Bath, 1950), Chlorella variegata, C. protothecoides, Coccomyxa dispar, Scenedesmus obliquus, $S$. quadricauda and Selenastrum minutum (R. A. Lewin, personal observations), appear completely smooth in electron micrographs. Those of two species of Chlamydomonas are striate (Lewin, Owen \& Melnick, 1951), but, whereas the width of the bands $(233 \AA)$ is in close agreement with that characteristic of cellulose fibrils, their regular parallel arrangement is not. Among other members of the Volvocales, the cell walls of Haematococcus (Motte, 1953) and of Platymonas (Kylin, 1935; Margalef, 1946) do not exhibit typical staining reactions for cellulose. Bailey \& Neish (1954) analysed the cell-wall residues of Chlorella cells from which the contents had been removed by exhaustive digestion with acetic acid and sodium chlorite. Of the insoluble 'holocellulose' $96 \%$ proved to consist of a polyglucose hemicellulose, soluble in hot aqueous KOH. True cellulose, if present, can therefore constitute only a small fraction of the wall substance of Chlorella.

In many unicellular algae, including members of the Volvocales and the Chlorococcales, young cells are formed endogenously and liberated by rupture of the parental wall. This permits the separation of shed walls from cells 
without prior chemical treatment, by the purely mechanical method of differential centrifugation. In this way the cell walls of Platymonas can readily be obtained free from other cellular material.

\section{METHODS}

Bacteria-free strains of Platymonas subcordiformis Hazen were isolated from tidal pools near: New Haven, Connecticut; Woods Hole, Massachusetts; La Jolla, California; and Halifax, Nova Scotia. Cultures were grown in sea-water media enriched with nitrate, phosphate and trace elements (Lewin, 1954), under constant light (2500 lux) and temperature $\left(20^{\circ}\right)$. Turbulence and a supply of carbon dioxide were maintained by the continuous passage of a stream of sterile air. Methods employed for the detection of bound sulphate, sugars, and amino acids in hydrolysates of the cell walls are described elsewhere (Lewin, 1956, 1958; Partridge, 1948).

\section{RESULTS}

Microscopic examination of suspensions of all isolates revealed an abundance of thin rod-like bodies among the organisms. These could be distinguished from shed flagella by their greater width and rigidity, but their nature remained obscure until examined under the electron microscope. It was then apparent that these rod-like structures were cast-off cell walls, more or less rolled up into scrolls (Pl. 1, fig. 2-5). Since, after each binary division, the liberation of daughter cells leaves one empty parental wall, cells and shed walls might be expected to occur in equal numbers. Thin sections of cells fixed with osmium tetroxide showed the wall as a smooth, homogeneous, electron-dense layer, perforated only to permit the exit of the flagella (Pl. 1, fig. 6).

The Woods Hole organism was grown under auxenic conditions for 6 weeks. The supernatant medium was then separated by centrifugation at $150-\mathbf{3 5 0} \mathrm{g}$ for $30 \mathrm{~min}$. and discarded The residue was re-suspended in filtered sea water, and was centrifuged in a tapered $15 \mathrm{ml}$. tube at $20-70 \mathrm{~g}$ for $15 \mathrm{~min}$. Most of the cells were thereby precipitated, leaving a milky suspension containing the cell walls. These were separated from the supernatant suspension by centrifugation at 500-700 $\mathrm{g}$ for $15 \mathrm{~min}$., and were then washed several times by suspension in distilled water and re-centrifugation. A pure white fraction was obtained, consisting of cell walls virtually free from whole cells. After drying at room temperature in a vacuum desiccator over concentrated sulphuric acid, the yields from a $1.5 \mathrm{l}$. culture were: cells, $1900 \mathrm{mg}$.; cell walls, $26 \cdot 4 \mathrm{mg}$.

The dried cell-wall preparation readily flaked off the surface of the glass container as a colourless, transparent film. A fragment was soaked in water and examined under the microscope; the cell walls appeared unchanged. Another portion was examined under crossed polaroids; although it was folded in various ways, there was no indication of birefringence such as was shown by a strand of cotton cellulose. An X-ray diffraction diagram of this material was kindly prepared and examined by Mr C. K. Johnson (Massa- 
chusetts Institute of Technology); it showed no characteristic spacings, indicating that the material was quite amorphous. A micro-Kjeldahl determination, carried out on a $5 \mathrm{mg}$. sample, indicated the presence of $0.55 \%$ nitrogen. Another $5 \mathrm{mg}$. sample was examined for organically-bound sulphate; this was found not to exceed $1 \%$ and was considered to be negligible.

Finally, hydrolysates of this wall preparation were chromatographed on paper, together with known sugars, etc., for reference. Chromatograms were sprayed with aniline phthalate for hexoses, pentoses and uronic acids; with dimethylaminobenzaldehyde for hexosamines; and with ninhydrin for amino acids. The predominant components appeared to be galactose and a uronic acid, together with traces of arabinose. Glucose and hexosamine were not detected. Traces indicating several amino acids (alanine, arginine, aspartic acid, glutamic acid, glycine, leucine/isoleucine, methionine/valine, proline, serine, threonine) appeared on the chromatograms, suggesting that the small amount of organic nitrogen might be attributed to protein contamination. A similar preparation of cell walls (23 $\mathrm{mg}$.) from the Halifax strain gave on hydrolysis essentially the same results, though in this case there was also a faint indication of mannose.

\section{DISCUSSION}

Paper chromatographic analysis of cell-wall hydrolysates, together with other evidence from electron microscopy, an X-ray diffraction diagram, etc., supports previous indications from staining reactions that the walls of Platymonas subcordiformis are not composed of cellulose. The question may be raised whether $\boldsymbol{P}$. subcordiformis is a true green alga, since it is the only member of the Chlorophyceae which has been found to possess flagella of the 'tinsel' type (Pitelka \& Schooley, 1955. Dr Pitelka has kindly confirmed this fact for all of the four strains we isolated.) A critical analysis of the plastid pigments might be expected to throw further light on this matter.

The electron micrographs were prepared in the School of Medicine, Yale University, and, with the assistance of Mr D. E. Philpott, in the Marine Biological Laboratory, Woods Hole, Mass.

\section{REFERENCES}

Barley, J. M. \& Neish, A. C. (1954). Starch synthesis in Chlorella vulgaris. Canad. J. Biochem. Physiol. 32, 452.

Fritsch, F. E. (1935). The Structure and Reproduction of the Algae. I. Cambridge University Press.

KreGer, D. R. (1957). New crystallite orientations of cellulose I in Spirogyra cellwalls. Nature, Lond. 180, 914.

Kyun, H. (1935). Über Rhodomonas, Platymonas und Prasinocladus. K. fysiogr. Sällsk. Lund Förhandl. 5, 217.

LEwiN, R. A. (1954). A marine Stichococcus sp. which requires vitamin $\mathbf{B}_{12}$ (cobalamin). J. gen. Microbiol. 10, 93.

LEwIN, R. A. (1956). Extracellular polysaccharides of green algae. Canad. $J$. Microbiol. 2, 665 .

Lewin, R. A. (1958). The mucilage tubes of Amphipleura rutilans. Limnol. \& Oceanogr. 3, 111. 
Lewin, R. A., Owen, M. J. \& Melnick, J. L. (1951). Cell-wall structure in Chlamydomonas. Exp. Cell Res. 2, 708.

Margaief, R. (1946). Contribución al conocimiento del género Platymonas (Volvocales). Col. bot., Barcinone 1, 95.

Motтe, J. (1953). Quelques données nouvelles concernant la paroi des planocytes d' Haematococcus pluvialis Flot. C.R. Acad. Sci. Paris, 236, 408.

Nicolai, E. \& Preston, R. D. (1952). Cell-wall studies in the Chlorophyceae. I. A general survey of submicroscopic structure in filamentous species. Proc. Roy. Soc. B, 140, 244.

Partridge, S. M. (1948). Filter-paper partition chromatography of sugars. I. General description and application to the quantitative analysis of sugar in apple juice, egg white and foetal blood of sheep. Biochem. J. 42, 238.

PrTelka, D. R. \& Schooley, C. N. (1955). Comparative morphology of some protistan flagella. Univ. Calif. Publ. Zool. 61, 79.

Sponsler, O. L. \& Bath, J. D. (1950). Electron microscope studies of submicroscopic structures of Ankistrodesmus falcatus. Amer. J. Bot. 36, 756.

\section{EXPLANATION OF PLATE 1}

Fig. 1. Platymonas subcordiformis. One organism, showing contents drawn away from wall. Figs. 2-5. Cell walls, showing various stages in rolling up to form scrolls.

Fig. 6. Section, showing portion of a cell and three more or less rolled-up cell walls. 
Journal of General Microbiology, Vol. 19, No. 1
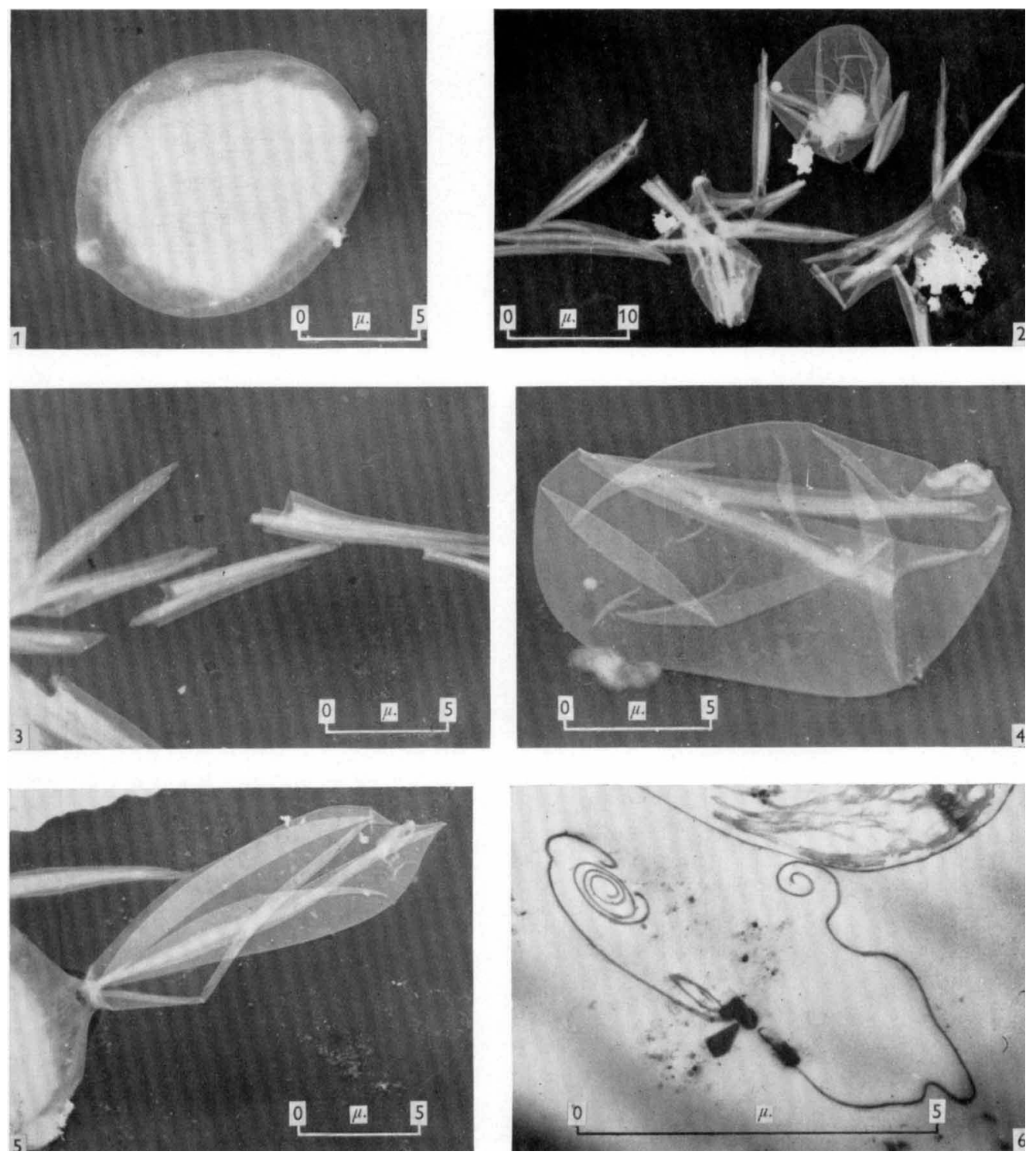

R. A. Lewin-Platymonas cell walls. Plate 1

(Facing p. 90) 